\title{
POP and PAH in Bizerte Lagoon, Tunisia
}

\author{
Trabelsi Souad, Ben Ameur Walid, Derouiche Abdekader, \\ Cheikh Mohamed and Driss Mohamed Ridha \\ Laboratory of Environmental Analytical Chemistry, \\ Faculty of Sciences, Bizerte, Zarzouna, \\ Tunisia
}

\section{Introduction}

Gas chromatography is the most recent branch of chromatography and includes all the chromatography processes in which the substance to be analyzed occurs in the gaseous or vapor state or can be converted into such a state. Although the first records of gas chromatography go back hundreds of years (Bayer, 1959), its true history began during World War II when a large industrial chemical company instituted a crash its development (Tietz, 1970). The first published work appeared in the early 1950's based on the successful experiments by James and Martin (1952). In the years between 1952 and 1956 the early apparatus came into sight. The success of gas chromatography is due to its simplicity of operation, high separation power and speed. Its use involves versatile applications not only to the field of chemistry but also biology, medicine, industrial research and control, environmental health and scientific studies.

In the field of environmental control the use of gas chromatography has allowed specific separations and measurements of toxic compounds on a large variety of matrices. Among these hazards, persistent organic pollutants (POPs) are carbon-based organic compounds and mixtures with toxicity and environmental persistence that include industrial products and byproducts. POPs can be transported far from their sites of release by environmental media to previously pristine locations such as the Arctic. Low POP levels might be increased by biomagnification through the transmission process in the food chain. They can be easily accumulated in the organism to levels that can potentially injure human health as well as the environment (Birnbaum, 1994; Hansen, 1998). There are 12 substances or substance groups prioritized for global action in the recently signed Stockholm Convention on Persistent Organic Pollutants, developed under the auspices of the United Nations Environment Programme (UNEP).

The 12 substances, the "dirty dozen," consist of eight kinds of pesticides, including dieldrin, aldrin, endrin, chlordane, heptachlor, DDT, toxaphene, mirex, two kinds of industrial chemicals [polychlorinated biphenyls (PCBs) and hexachlorobenzene (HCB)], and two kinds of byproducts (polychlorinated dibenzofurans and polychlorinated dibenzo-p-dioxins) (Stockholm Convention on Persistent Organic Pollutants, 2001). There are four characteristic parameters (persistence, bioaccumulation, toxicity, and long-range environmental transport), which can distinguish POPs from a multitude of other organic chemicals. All 12 
prioritized POPs or their breakdown products rank high to extreme on measurements of these parameters. Reproductive, developmental, behavioral, neurological, endocrine, and immune adverse health effects on people have been linked to POPs. POP pollution has touched every region in the world. Much attention is given to POP contamination problems, and strong action has been taken by most developed and developing nations.

Among organic pollutants, polycyclic aromatic hydrocarbons (PAHs) are the most ubiquitous and constitute a major group of marine environmental contaminants. PAH show a marked hydrophobic character, resistance to biodegradation (Neff, 1979) and adverse effects on health (carcinogenic and/or mutagenic activity) (Singh et al., 1998) and ecosystem (Long et al., 1995). The carcinogenic properties of some compounds, coupled with the stability of PAHs during their atmospheric and aquatic transport, and their widespread occurrence have, in recent years, generated interest in studying their sources, distribution, transport mechanisms, environmental impact and fate (Bouloubassi \& Saliot, 1993). Moreover, PAHs are quickly adsorbed onto suspended particulate. These findings prompted US EPA to include 16 PAHs within a priority pollutant list. Therefore, guidelines were proposed in order to assist the management of polluted sediments (Swarz, 1999). PAHs of coastal sediments are due to both anthropogenic and natural sources (NRC, 1985). Among anthropogenic factors, petrogenic and pyrolytic sources are the most important. Although somewhat controversial, the aromatisation of cyclic compounds could be a further source of PAHs (LaFlamme \& Hites, 1978). Perylene is a good example of a PAH substance of biological origin found in both marine and freshwater sediments (LaFlamme \& Hites, 1978).

Again, PAHs from pyrolytic and petrogenic sources exhibit different chemical behaviour and distribution in marine sediments. In particular, PAHs from pyrolytic processes are more strongly associated with sediments and much more resistant to microbial degradation than PAHs of petrogenic origin (Gustafsson et al., 1997).

The Bizerte lagoon is located in the northernmost part of Tunisia, between latitudes $N^{\circ} 3708^{\prime}$ and $\mathrm{N}^{\circ} 3716^{\prime}$ and consists of a depression having a surface area of about $150 \mathrm{~km} 2$ and maximum depth of $12 \mathrm{~m}$. This lagoon is known for its geostrategic position since it links the Mediterranean Sea to an internal lake (Ichkeul), which is classified as a national park and world heritage.

Many decades ago, the lagoon is known as a fishery and aquaculture park related to the presence of three mytiliculture sectors especially Menzel Jemil park which is the most productive site. Many years ago, the lagoon's banks were subjected to both urbanization and industrialization. Manufacturing facilities such as iron and steel complex, the naval construction and tyre production, urban wastewater and open-dumping-type municipal or industrial solid waste landfills scattered around the lagoon could have led to ecological perturbation of this fragile environment.

Two previous preliminary studies showed that superficial coastal sediments from Bizerte lagoon were moderately contaminated by PCB (Derouiche et al., 2004) and PAH (Trabelsi \& Driss, 2005). In order to perform the current contamination status in the study area data compilation and reporting together with data for POC contamination are the final steps for a comprehensive survey of Bizerte lagoon for the levels of organic contaminants, and represent an attempt to understand the effects of the agricultural and industrial chemical 
pollution. As a result, the following interpretation and discussion will be focused on the 15 organochlorine pesticides, 20 PCBs and 20 PAHs in sediment. Additionally, data for combination of multivariate approaches were applied in order to identify possible input sources.

\section{Materials and methods}

\subsection{Sampling}

Sediment samples from Bizerte lagoon were collected in December 2001 using a Van Veen grap. The first top centimetre $(500 \mathrm{~g})$ was placed in an aluminium container and frozen on dry ice, then transferred to the laboratory with no exposure to light. Fifteen sampling stations in coastal and central areas in the lagoon are shown in Fig.1.

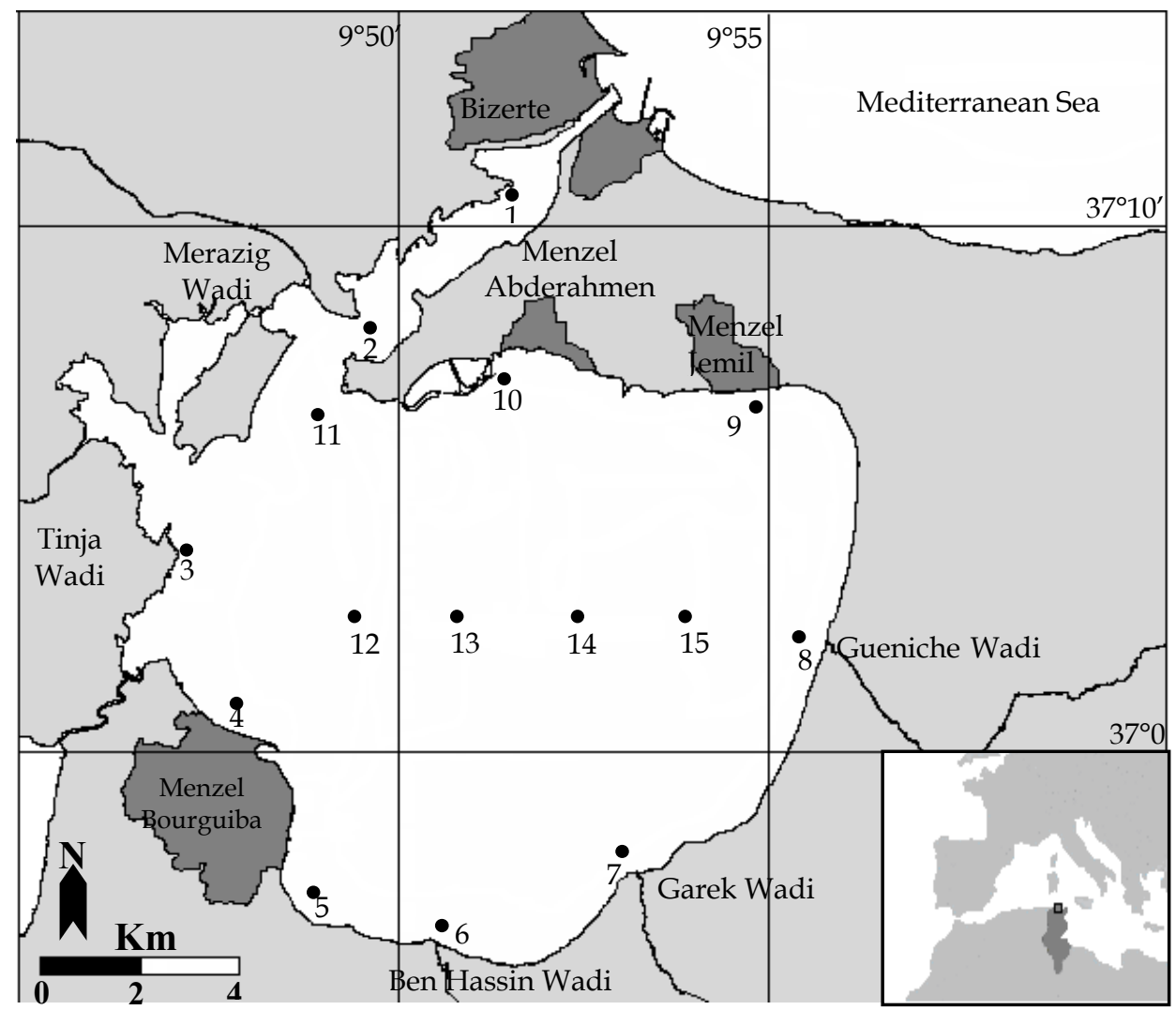

Fig. 1. Study area and sampling stations 


\subsection{Grain size and TOC determinations}

The fraction of the sediment having a grain size $<63 \mu \mathrm{m}$ (silt+clay=pelite) was determined gravimetrically after wet sieving. A representative sub-sample was taken for organic carbon (TOC) determination, according to the revised Walkly-Black titration method conducted in accordance with clause 3 of BS 1377: Part 3 (BSI, 1990). Briefly, $2 \mathrm{~g}$ dried sediments were treated with $10 \mathrm{~mL}$ of $1.000 \mathrm{~N}$ potassium dichromate followed by the rapid addition of $20 \mathrm{~mL}$ of concentrated $\mathrm{H}_{2} \mathrm{SO}_{4}$ containing $0.5 \mathrm{~g}$ silver sulphate, to precipitate chloride ions. Samples were allowed to cool uniformly to room temperature for $30 \mathrm{~min}\left(\right.$ at $\left.20^{\circ} \mathrm{C}\right)$, then the mixture was diluted by $200 \mathrm{~mL}$ of double-distilled water, and $10 \mathrm{~mL}$ of phosphoric acid was added. Finally, the extra dichromate was back titrated with iron (II) sulphate solution using barium diphenylamine sulphonate as an indicator.

\subsection{Instrumental}

Quantitative analyses of PAHs, PCBs and OCPs in sediments were accomplished by an Agilent 6890 A gas chromatography (GC). The column used for analysis of PCBs and OCPs was fused silica capillary PTE-5 (30 $\mathrm{mx} 0.32 \mu \mathrm{m}$ thickness). The operating conditions were as follows: Injector temperature $250^{\circ} \mathrm{C}$; detector $300^{\circ} \mathrm{C}$; oven temperature: initial $50^{\circ} \mathrm{C}$ for 2 min, programmed to $160^{\circ} \mathrm{C}$ at $5^{\circ} \mathrm{C} / \mathrm{min}$, followed at $2^{\circ} \mathrm{C} / \mathrm{min}$ to $260^{\circ} \mathrm{C}$ for $10 \mathrm{~min}$; carrier gas: helium at a flow rate (constant flow) of $1.5 \mathrm{~mL} / \mathrm{min}$; detector make-up gas was nitrogen at a flow rate of $60 \mathrm{~mL} / \mathrm{min}$; sample injection volume $2 \mu \mathrm{l}$; injection mode: splitless for $1 \mathrm{~min}$.

PAHs separation was accomplished by a HP1 fused silica column ( $30 \mathrm{~m}$ length $0.32 \mathrm{~mm}$ i.d., $0.25 \mu \mathrm{m}$ film thickness) and flame ionisation detector (FID). The oven temperature was held at $50^{\circ} \mathrm{C}$ for $1 \mathrm{~min}$, then programmed at $20^{\circ} \mathrm{C} / \mathrm{min}$ to $150^{\circ} \mathrm{C}$ then at $8^{\circ} \mathrm{C} / \mathrm{min}$ to $280^{\circ} \mathrm{C}$ and held at $280^{\circ} \mathrm{C}$ for $15 \mathrm{~min}$. The injector was maintained at $280^{\circ} \mathrm{C}$ and the detector at $300^{\circ} \mathrm{C}$. Helium was used as the carrier gas.

\subsection{Standards}

Twenty PAH compounds were analysed in this study, including sixteen US EPA priority PAHs (naphthalene (Naph), acenaphthylene (Act), acenaphthene (Ace), fluorene (Fl), phenanthrene (Phe), anthracene $(\mathrm{An})$, fluoranthene $(\mathrm{Ft})$, pyrene $(\mathrm{Py})$, benzo[a]anthracene $(\mathrm{B}[\mathrm{a}] \mathrm{an})$, chrysene (Chy), benzo[k]fluoranthene $(\mathrm{B}[\mathrm{k}] \mathrm{ft})$, benzo[b]fluoranthene $(\mathrm{B}[\mathrm{b}] \mathrm{ft})$, benzo[a]pyrene $(\mathrm{B}[\mathrm{a}] \mathrm{py})$, indeno $[1,2,3-\mathrm{cd}]$ pyrene (Ind), dibenzo[a,h]anthracene $(\mathrm{D}[\mathrm{a}, \mathrm{h}]$ an) and benzo[ghi] perylene (B[ghi]pe) $(99 \%$, Supelco), perylene $(99 \%)$ and three alkylatyed PAHs [2-methyl-anthracene (99\%), 9-methyl-anthracene (97\%) and 1-methyl-phenanthrene) (99\%)] from Jansen Chemica.

A mixed PCB standard reference material (SRM 1493) from the National Institute of Standard and Technology (USA) was used for and containing PCB8, PCB18, PCB28, PCB44, PCB52, PCB66, PCB77, PCB101, PCB105, PCB118, PCB126, PCB128, PCB138, PCB153, PCB170, PCB180, PCB187, PCB195, PCB206 and PCB209 in IUPAC number.

The standard reference material SRM 2261, obtained from National Institute of standards and Technology, was used to quantify the 15 examinated organochlorine pesticides: HCB, lindane, Heptachlor, aldrine, heptachlorepoxyde, o, $\mathrm{p}^{\prime}$-DDE, cis-chlordane, trans-nonachlor, dieldrine, $\mathrm{p}, \mathrm{p}^{\prime}$-DDE, $\mathrm{o}, \mathrm{p}^{\prime}$-DDD, $\mathrm{p}, \mathrm{p}^{\prime}$-DDD, $\mathrm{o}, \mathrm{p}^{\prime}$-DDT, $\mathrm{p}, \mathrm{p}^{\prime}$-DDT and mirex. 


\subsection{Analytical procedure}

The analytical procedure used for PAHs follows the modified method described by Kelly et al. (2000). Briefly, 20g of dried sediments were extracted using alkaline saponification with $\mathrm{KOH} / \mathrm{MeOH}(2 \mathrm{~N}, 100 \mathrm{~mL})$. Digests were filtered and extracted with n-hexane, and dried over previously roasted $\mathrm{Na}_{2} \mathrm{SO}_{4}$. After sulphur removal by activated copper, the solution was reduced to $2 \mathrm{~mL}$ and dropped into a column (i.d. $=10 \mathrm{~mm}$ ), slurry packed with $2 \mathrm{~g}$ of activated silica gel 60 , then eluted with a sequence of $15 \mathrm{~mL}$ hexane (fraction 1-discarded) and $30 \mathrm{~mL}$ of hexane: dichloromethane (9:1; fraction 2) which contained the PAHs. The eluate was concentrated to $0.5 \mathrm{~mL}$ in a micro-Kuderna-Danish evaporator under a gentle stream of nitrogen.

PAHs were identified and quantified by comparison with known standards injected under the same conditions. Certified standard reference marine sediment (EC-7, National Water Research Institute, Canada) was used in the evaluation of the analytical method. The mean recovery of certified PAHs in the extract was $86 \%$. The detection limit of each PAH has an average of about $0.03 \mathrm{ngg}-1$ for the sediment samples.

The analytical procedure of OCPs and PCBs in sediments is a modification of the method described by Montone et al. (2001). Briefly, $30 \mathrm{~g}$ of dried sediment were extracted with 300 $\mathrm{mL}$ of $\mathrm{n}$-hexane in a Soxhlet apparatus for $12 \mathrm{~h}$. Activated copper treatment and sulphuric acid clean-up procedures were employed to remove elemental sulphur and other interfering materials. The sample extracts were further purified in a column (i.d. $=10 \mathrm{~mm}$ ), slurry packed with $5 \mathrm{~g}$ of florisil and then eluted with a sequence of $40 \mathrm{~mL}$ hexane (fraction contained OCPs) and $40 \mathrm{~mL}$ of hexane: dichloromethane (9:1; fraction 2) which contained the PCBs. Each fraction was concentrated to $1 \mathrm{~mL}$ in a micro-Kuderna-Danish evaporator under a gentle stream of nitrogen.

The whole analytical procedure was validated by analysing EC-3 sediment reference materials from National Water Research Institute (Canada). The recoveries of studied PCBs in the extract using the same methodology were $>90 \%$. The identification of compounds was deduced from their retention times and quantification was based on peak area measurement as well comparison with responses of the mixed PCBs standard reference material (SRM 1493).

\section{Results and discussion}

\subsection{Sediment characteristics}

Different opinions exist regarding the relation between POPs concentration and characteristics of sediments. Several authors have observed that organochlorines and PAH in the sediments are mainly associated with the organic matter (Neff, 1979; Knezovich et al., 1987; Doong et al., 2002), and their total content depends on grain size distribution (Law \& Andrulewicz, 1983; Doong et al., 2002).

TOC contents ranged from $0.23 \%$ to $2.95 \%$ in the study area (Table 1 ). Organic matter contents of sediments appear especially high (>3\% of dry weight) in the central zone of the lagoon and are relatively low in the peripheral zones $(<1 \%)$. Sediments from stations 4 and 5 which are adjacent to area of Menzel Bourguiba city (about 100000 habitants), known by its big urban and industrial activities, seem to be especially rich in organic matter $(>1.5 \%)$. This 
also seems to be true for the Bizerte and neighbouring cities. This finding could be explained by the massive discharge (before 1997) of raw municipal and/or industrial wastewater before implantation of wastewater plants in these cities. The mouths of Guenniche and Garek wadis are marked by a low deposit of organic matter $(<0.5 \%)$.

The pelite (fraction of the sediment having a grain size $<63 \mu \mathrm{m}$ (silt+clay)) is given in Table1. The samples from Bizerte lagoon show large variations in sediments type, from very coarse $(5 \%$ are $<63 \mu \mathrm{m}$ at station 1$)$ to very fine grained $(80 \%$ are $<63 \mu \mathrm{m}$ in the central zone of the lagoon). Low pelite content (11\%) was also found in sandy sediments from the eastern part (station 9). In mouths of Guenniche, Ben Hassin and Garek wadis, the sediments were less fine-grained with pelite varying from 21 to $37 \%$ of dry sediment.

The major part of Bizerte lagoon basin is a depocenter of fine grey mud generally saturated with sodium ions (sodic clays) having a high cation exchange capacity exceeding 10 meq/100g dry sediment (Hamdi et al., 2002). However, a sandy environment, mainly in the southern part where coarse sediments are mixed with shell debris, characterizes the nearshoreline contour.

The kinetic behavior of hydrophobic organic pollutants is much influenced by organic carbon contents in sediments and soils (Karickhoff et al, 1979).

Our study shows that the concentrations of $\sum$ DDT and $\sum$ POC, in sediments from Bizerte lagoon are correlated well with TOC contents $(\mathrm{r}=0.553, \mathrm{p}<0.05)$, which is possibly due to the less lipophilic and more volatile nature of $\mathrm{HCH}$ relative to the DDTs.

Correlation analysis shows negative correlations between total PAHs contents/TOC contents and the pelite/PAH levels. These results indicate that the observed distribution of PAHs was not governed by sedimentary characteristics such as TOC contents and the fraction of pelite (grain size less than $63 \mu \mathrm{m}$ ), but, it might be due to the localised source inputs. However, positive and significant usual correlations $\left(R_{2}=0.70\right)$ were observed between the sediment contents of fine fraction and those of TOC contents (Johnson, 1986). Indeed this association between fine matter and the organic particles is especially due to a common phenomenon in Mediterranean lagoons called flocculation (Aloisi et al., 1975).

\subsection{PAH Composition source identification and ecotoxicological concerns}

The distribution of various PAH in the sediments from 15 sampling stations reveals a wide range of fluctuations, as delineated in Table 1.Twenty individual PAHs were determined which comprising two to six ring, with three alkyl-substituted homologues. Total PAHs concentrations ranged from 20 at station 15 to 449 ngg- $^{-1}$ dry weight at station 5 with a mean average of 183 ngg- 1 dry wt. The lower concentrations were detected in the middle part of the lagoon and the eastern zone which is characterized by an agricultural activity and where several wadis flow directly into the lagoon. The highest contents are found at stations 1, 2, 4, 5, 6 and 11 where an intensive urban and/or industrial activities were carried out.

Certain diagnostic ratios have been widely used in order to identify and quantify the contribution of each sources of PAH contamination. The reported approaches should be treated with caution. 


\begin{tabular}{|c|c|c|c|c|c|c|c|c|c|c|c|c|c|c|c|}
\hline & \multicolumn{15}{|c|}{ Stations } \\
\hline PAH & 1 & 2 & 3 & 4 & 5 & 6 & 7 & 8 & 9 & 10 & 11 & 12 & 13 & 14 & 15 \\
\hline $\begin{array}{l}\mathrm{Na} \\
\mathrm{ph}\end{array}$ & 5.42 & 3 & 3.26 & 3.44 & 10.02 & nd & 3.3 & 9.54 & nd & 12.82 & 6.69 & 2.14 & nd & $\mathrm{Nd}$ & nd \\
\hline Ace & 0.28 & 0.77 & 0.89 & 0.88 & 0.24 & nd & 3.29 & 4.65 & 0.27 & 0.44 & 0.26 & 0.42 & 0.93 & 2.57 & nd \\
\hline Act & nd & nd & nd & nd & 1,45 & nd & nd & nd & nd & nd & nd & nd & nd & $\mathrm{Nd}$ & nd \\
\hline $\mathrm{Fl}$ & nd & nd & nd & nd & 7,8 & nd & nd & nd & nd & nd & nd & nd & nd & $\mathrm{Nd}$ & nd \\
\hline 2-me-An & 0.08 & 0.12 & 0.18 & 0.5 & 0.1 & 0.32 & 0.15 & 0.07 & nd & 0.05 & 0.12 & nd & nd & $\mathrm{Nd}$ & nd \\
\hline $\begin{array}{l}\text { 1-mé- } \\
\text { Phe }\end{array}$ & 0.73 & 1.87 & 3 & nd & 1.91 & 1.98 & nd & 0.36 & 0.36 & nd & nd & nd & nd & $\mathrm{Nd}$ & nd \\
\hline 9-me-An & \begin{tabular}{|l|}
0.08 \\
\end{tabular} & 0.09 & 0.08 & 1.4 & 0.06 & nd & nd & $\mathrm{Nd}$ & nd & nd & 0.7 & 0.07 & nd & $\mathrm{Nd}$ & nd \\
\hline Phe & 30.85 & 19.97 & 26.61 & 27.1 & 54.64 & nd & nd & $\mathrm{Nd}$ & 13.93 & 27.19 & 13.08 & 29.96 & 22.71 & 30.81 & 7.99 \\
\hline $\mathrm{An}$ & 2.8 & nd & 7.72 & 13.72 & 30.68 & 45.48 & $\left.16.05\right|^{2}$ & 20.63 & 3.49 & \begin{tabular}{|l|}
6.4 \\
\end{tabular} & 1.75 & nd & nd & 2.9 & nd \\
\hline $\mathrm{Ft}$ & 44.2 & 96.48 & nd & 70.09 & 45.86 & 49.77 & 20.16 & 36.78 & 11.23 & 17.34 & 26.37 & 22.32 & 18.96 & 19.08 & 8.66 \\
\hline Py & 91.99 & 64.37 & 21.7 & 33.7 & 176.06 & nd & nd & $\mathrm{Nd}$ & 14.1 & 9.51 & 26.89 & 19.52 & 17.67 & $\mathrm{Nd}$ & nd \\
\hline $\begin{array}{c}\mathrm{B}(\mathrm{a}) \\
\text { an }\end{array}$ & 38.47 & 65.65 & nd & nd & 33.04 & nd & nd & $\mathrm{Nd}$ & nd & nd & nd & 9.78 & 16.53 & 7.96 & nd \\
\hline Chy & 27.8 & 52.08 & nd & 140.94 & nd & 34.68 & nd & $\mathrm{Nd}$ & 72.78 & nd & 106.49 & 11.52 & 10.44 & 9.22 & nd \\
\hline $\begin{array}{c}\mathrm{B}(\mathrm{b}) \\
\mathrm{ft}\end{array}$ & 32.33 & 2.43 & nd & 8.72 & nd & 31.74 & nd & $\mathrm{Nd}$ & nd & 34,8 & 48.77 & 11.2 & nd & $\mathrm{Nd}$ & 3.76 \\
\hline $\begin{array}{c}\mathrm{B}(\mathrm{k}) \\
\mathrm{Ft}\end{array}$ & nd & nd & nd & 60.73 & nd & nd & nd & $\mathrm{Nd}$ & nd & nd & 4.16 & nd & nd & $\mathrm{Nd}$ & nd \\
\hline $\begin{array}{l}\text { B(a) } \\
\text { py }\end{array}$ & 20.18 & 51.6 & 39.56 & 36.67 & 35.54 & nd & 13.03 & $\mathrm{Nd}$ & nd & 18.96 & nd & 20.86 & nd & $\mathrm{Nd}$ & nd \\
\hline Per & 0.05 & 0.05 & nd & 0.08 & nd & 0.68 & nd & 0.06 & nd & nd & 0.28 & 0.09 & 0.07 & 0.06 & nd \\
\hline Ind & nd & 36.75 & nd & nd & 42.31 & nd & nd & $\mathrm{Nd}$ & nd & nd & nd & nd & nd & $\mathrm{Nd}$ & nd \\
\hline $\begin{array}{c}\mathrm{D}(\mathrm{a}, \mathrm{h}) \\
\text { an }\end{array}$ & nd & nd & nd & nd & 3.11 & nd & nd & $\mathrm{Nd}$ & nd & 13.61 & nd & nd & nd & $\mathrm{Nd}$ & nd \\
\hline $\begin{array}{l}\text { B(ghi) } \\
\text { pe }\end{array}$ & nd & nd & nd & nd & 6.44 & nd & nd & $\mathrm{Nd}$ & nd & nd & nd & nd & nd & $\mathrm{Nd}$ & nd \\
\hline $\begin{array}{c}\text { Tot } \\
\text { PAH } \\
\end{array}$ & & 123 & 03 & & & 16 & & 2.09 & 61 & 17 & 5 & 27.88 & 7.31 & 72.6 & 20.41 \\
\hline $\begin{array}{l}\text { OC } \\
(\%)\end{array}$ & 0.3 & 1.85 & 1.91 & 1.87 & 1.87 & 0.87 & 0.23 & 0.36 & 0.95 & 0.9 & 0.82 & 1.8 & 2.6 & 3.2 & 2.1 \\
\hline elite (g & 5.03 & 42.04 & 64.23 & 88.51 & 59.98 & 22.75 & 37.58 & 21.47 & 11.29 & 23.13 & 51.56 & 86.24 & 91. & 6.41 & \\
\hline
\end{tabular}

Table 1. Levels of PAHs (ngg-1 dry wt), percentage of organic carbon (\%OC) and pelite fraction $(\mathrm{g})$ in surface sediments from 15 sampling stations

In contrast to pyrogenic sources, petrogenic sources are characterized by Phe/An ratio $>10$, Ft/Py <1 and B(a)An/Chy<1 (Budzinski et al., 1997). On the other hand, some PAHs, such as perylene come from diagenesis processes of biogenic precursors (Venkatesan, 1988).

Recently, alkylated PAHs also, have been proved useful in petroleum-related fingerprinting by comparing their relative individual magnitudes in sediments (Page et al., 1999).

Budzinski et al., (1997) had given attention to distribution of low and high molecular weight $\mathrm{PAH}$ (LPAH and HPAHs, respectively) as a reliable tool for discriminating the petrogenic/pyrolytic origin of PAHs. The higher the LPAHs/HPAHs ratio, the higher the prevalence of petrogenesis on pyrolytic origin of PAHs. 
Concentrations of PAHs are mostly dominated by high molecular weight compound (PAHs with 4 to 6 rings). The LPAH/HPAHs ratios are very low, from 0.06 to 1 and the only congener that is nearly always present is phenanthrene. This means that probably high temperature combustion processes were the predominant source of PAHs contamination (Canton and Grimalt, 1992). This information is confirmed by the low concentrations of the alkyl homologues (methyl-anthracene/anthracene and methyl-phenanthrene/ phenanthrene). Indeed, close similarities between the relative distribution of methylanthracene/anthracene and methyl-phenanthrene/phenanthrene ratios for sample sediments analyzed in the study area were observed but less than unit values of alkyl to parent anthracene and phenanthrene were detected for all sample sediments.

Additionally, the Phe/An and Ft/Py ratios can be used to assess the relative importance of the sources and the effect of diagenetic changes (Soclo et al., 2000). Phe/An ratios span from 3.45 to 11 and Ft/Py ratios range from 0.26 to 2 . For instance $\mathrm{Phe} / \mathrm{An}>10$ and $\mathrm{Ft} / \mathrm{Py}<1$, which are characteristics of $\mathrm{PAH}$ petrogenic contamination, were found only at station 1 . Furthermore, chrysene and $\mathrm{B}(\mathrm{a})$ an derive from pyrolytic sources in ratio that should be lower than 1 (Soclo et al., 2000). Most values in our samples were closed to 1 or slightly higher. This may be due to some influence from petrogenic contamination or to the degradation of the less stable B(a)An.

Perylene, which may be of natural origin, was determined at very lower concentrations (Table1). Early studies reported diagenetic formation of perylene from terrestrial precursors in anoxic conditions (Aizenshtat, 1973). However, perylene is also produced during pyrolytic processes (Venkatesan, 1988). The low relative abundance of perylene in the study area argues for a dominant pyrolytic origin (Venkatesan, 1988).

Distribution of PAHs in Bizerte Lagoon sediment reveals general and moderate contamination. Based on the investigation of approaches reported above our results reveal that PAH contamination could be related to urban and or industrial activities. The data found indicate that sediments for stations 1, 2 and 11 were characterized by pyrogenic PAH contamination when examining the LPAHs/HPAHs, methylphenanthrene/phenanthrene, methylanthracene/anthracene ratios. However, Phe/ $\mathrm{An}$ and $\mathrm{Ft} / \mathrm{Py}$ ratios reveal $\mathrm{PAH}$ petrogenic contamination only at station 1 . PAH inputs in this area are most likely related to the intensive traffic of boats and industrial activities. The later station is localised in an area where there are oil refinery and used oil recycling activities which probably constitute the main sources of contamination by petrogenic PAHs. Stations 2 and 11 are near a base of the Tunisian Military Marine and a solid waste landfill. Stations 4, 5 and 6 are located near Menzel Bourguiba city, where intensive industrial activity is carried out, including the metallurgic industry, naval construction and tyre production. In addition, there are several local wastewater discharges in this area. Additionally, PAH concentrations for all stations were also plotted using a ternary diagram to investigate combinations of PAHs that may have similar sources and modes of inputs. The plot reveals two notable groups of stations. The first includes stations 1,2 and 11 which are located in the channel of navigation of boats. In the second group, we distinguish stations 4,5 and 6, which are closed to the urban and intensive productive industrial zone (city of Menzel Bourguiba).

The middle part $(12,13,14$ and 15) of the lagoon shows a clear tendency of PAH concentration to decrease from west to east part. The decrease of PAH levels is logically in agreement with the increasing distance from urbanised and/or industrial area. 
To assess potential environmental impacts of PAHs in sediments, the concentrations of PAHs in sediments can be compared with certain threshold values proposed by the US National Oceanic and Atmospheric Administration, e.g. the effects-range low (ER-L) (which is a sediment quality guideline below which the chemical concentration in the sediments would be expected to rarely have adverse biological effects) and the effect-range medium (ER-M) (a level above which adverse biological effects occur frequently).

The concentrations found for all stations ranged from 20 to 449 ngg-1 dry weight which are below the ER-L (4000 ngg-1) and the ER-M (45000 ngg-1). This range represents a relatively clean environment.

\subsection{Contamination status of POPs}

\subsubsection{PCB composition and sources identification and ecotoxicological concerns}

The distribution of various PCB in the sediments from 15 sampling stations reveals that the $\Sigma$ PCB ranged from 0.89 to 6.63 ngg-1 $^{-1}$ (Table 2). Fig. 2 shows the geographic distribution of the $\Sigma \mathrm{PCB}$ in the whole study area, the contents of total PCB in sediment vary from a site to another.

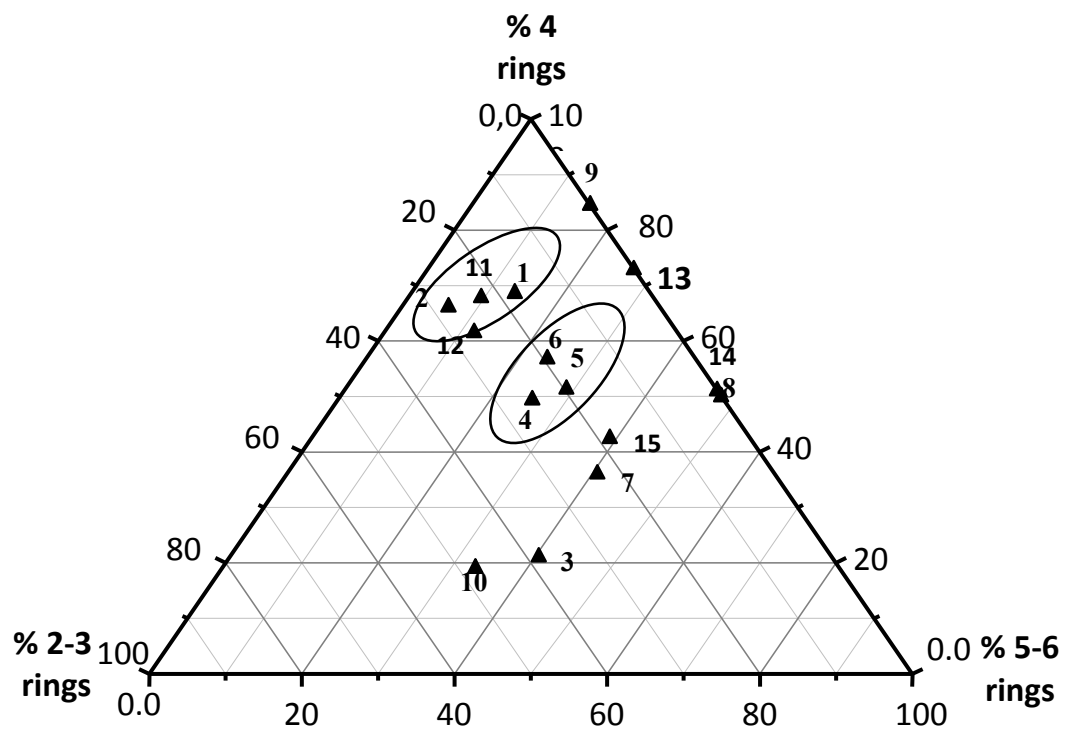

Fig. 2. ternary diagram of the distribution of low, mid and high molecular weight PAHs

This result reflects geographic distribution of PCB level of contamination. For the coastal sites, the highest PCB concentrations ranged from 4.39 to $6.63 \mathrm{ng} \mathrm{g}^{-1}$ were detected at northern part covered sites 1, 2, 10, and 11 and at southwest zone (site 5). Sediments collected from the other coastal sites are slightly contaminated ( $\sum$ PCB ranged from 0.89 to $2.58 \mathrm{ng}$ g- 1 ). Relatively high PCB concentrations were also found in samples collected from sites 12, 13, 14, and 15. These stations are located in the central zone of the lagoon and are the deepest. 


\begin{tabular}{|c|c|c|c|c|c|c|c|c|c|c|c|c|c|c|c|}
\hline & \multicolumn{15}{|c|}{ Stations } \\
\hline PCB & 1 & 2 & 3 & 4 & 5 & 6 & 7 & 8 & 9 & 10 & 11 & 12 & 13 & 14 & 15 \\
\hline PCB8 & 0.23 & 0.31 & 0.05 & 0.46 & 0.18 & 0.33 & 0.40 & 0.34 & 0.36 & 0.76 & 0.28 & 0.69 & 0.86 & 1.38 & 0.96 \\
\hline PCB18 & nd & nd & nd & nd & nd & nd & nd & nd & 0.48 & 0.31 & 0.19 & 0.37 & 0.31 & 0.80 & 0.45 \\
\hline PCB28 & 0.15 & 0.22 & nd & 0.24 & nd & nd & 0.23 & 0.19 & 0.22 & 0.35 & 0.20 & 0.32 & 0.31 & 0.52 & 0.32 \\
\hline PCB 52 & 0.11 & 0.44 & nd & 0.15 & nd & 0.07 & 0.09 & 0.07 & 0.08 & 0.32 & 0.22 & 0.36 & 0.13 & 0.10 & 0.08 \\
\hline PCB 44 & nd & 0.21 & nd & nd & nd & 0.06 & nd & nd & 0.10 & 0.11 & nd & 0.12 & 0.10 & 0.10 & 0.06 \\
\hline PCB 66 & nd & 0.10 & 0.09 & nd & 0.03 & nd & 0.06 & nd & 0.11 & 0.17 & 0.36 & 0.20 & 0.12 & 0.15 & 0.07 \\
\hline PCB 77 & nd & nd & nd & nd & nd & nd & nd & nd & 0.41 & 0.29 & 0.44 & 0.99 & 0.18 & 0.26 & 0.09 \\
\hline PCB 101 & 0.32 & 0.64 & nd & 0.15 & 0.19 & 0.06 & 0.07 & nd & 0.07 & 0.25 & 0.31 & 0.23 & 0.37 & 0.11 & nd \\
\hline PCB 118 & nd & 0.54 & 0.26 & 0.09 & 0.09 & nd & nd & nd & 0.17 & 0.17 & 0.38 & 0.27 & 0.16 & 0.12 & 0.07 \\
\hline PCB 105 & 0.15 & 0.23 & 0.15 & 0.08 & 0.07 & 0.02 & nd & nd & nd & 0.06 & 0.15 & 0.08 & nd & 0.08 & nd \\
\hline PCB 153 & 0.80 & 0.73 & 0.09 & 0.40 & 1.09 & 0.23 & 0.10 & 0.08 & 0.10 & 0.51 & 0.91 & 0.78 & 0.62 & 0.37 & 0.34 \\
\hline PCB 138 & 0.95 & 0.85 & nd & 0.38 & 1.01 & 0.19 & 0.08 & 0.07 & nd & 0.40 & 0.72 & 0.58 & 0.40 & 0.32 & 0.25 \\
\hline PCB 128 & 0.17 & 0.29 & nd & nd & 0.18 & 0.03 & nd & nd & nd & 0.04 & 0.08 & 0.04 & 0.04 & 0.07 & 0.08 \\
\hline РСB 187 & 0.22 & 0.15 & 0.11 & 0.12 & 0.36 & 0.07 & nd & nd & 0.06 & 0.22 & 0.55 & 0.40 & 0.27 & 0.22 & 0.19 \\
\hline PCB 180 & 0.70 & 0.34 & 0.19 & 0.23 & 0.94 & 0.15 & nd & 0.05 & 0.25 & 0.41 & 1.18 & 0.76 & 0.55 & 0.27 & 0.23 \\
\hline PCB 170 & 0.50 & 0.20 & 0.12 & 0.15 & 0.57 & 0.07 & nd & nd & 0.06 & 0.18 & 0.44 & 0.27 & 0.16 & 0.14 & 0.12 \\
\hline PCB 195 & 0.09 & 0.09 & nd & 0.10 & nd & nd & 0.09 & 0.08 & nd & 0.05 & 0.09 & 0.04 & 0.03 & 0.02 & 0.02 \\
\hline PCB 206 & nd & nd & nd & nd & nd & nd & nd & nd & nd & 0.01 & 0.03 & 0.03 & 0.01 & nd & nd \\
\hline PCB 209 & nd & nd & nd & 0.04 & 0.07 & nd & nd & nd & nd & 0.08 & 0.10 & 0.10 & 0.09 & 0.09 & 0.07 \\
\hline$\sum \mathrm{PCB}$ & 4.39 & 5.34 & 1.51 & 2.58 & 4.77 & 1.29 & 1.12 & 0.89 & 2.48 & 4.68 & 6.63 & 6.62 & 4.69 & 5.13 & 3.40 \\
\hline
\end{tabular}

Table 2. Concentrations (ngg-1, dry weight) of PCBs in surface sediments from 15 sampling stations

Our sediment investigation revealed the general prevalence of lower and mid molecular weight PCBs. The PCB congeners pattern was dominated by bi-PCBs (100\%), Tri-PCB (PCB28; 80\%) and tetra-PCB (PCB52; 86\%). Mid-PCBs also dominated the PCBs congeners pattern. PCB congeners proportions consisted of the following distribution: PCB153 (100\%), PCB180 $(93 \%)$ and PCB $(187,170,138)$ accounting $86 \%$ of total PCBs composition. However, relatively moderate percentage of the high chlorinated congeners, such as octa-PCBs $(73 \%)$, were found in this study. Sediment collected at locations 4, 5, 6, 14 and 15 contained great proportions of di-, tri-, and tetra-PCB, whereas those from locations 1, 2, 11, 10, 9,8 and 7 had higher proportions of penta-, hexa-, and hepta-PCBs.

A number of previous studies have showed the production of PCBs during the steel manufacturing processes (Alcock et al., 1999; Buekens et al., 2001). This is due to the presence of PCBs in fly ash generated from burning coal during the iron ore sintering process (Biterna \& Voutsa, 2005). The later sites (1, 2, 11, 10, 9, 8 and 7) are close to some industries established on the circumference of the lagoon (an iron and steel plant, a cement factory, and a refinery).

The human population around the lagoon is estimated at 163,000 inhabitants (census of 2004) of which approximately $70 \%$ are concentrated in Bizerte town. The other main important towns bordering the lagoon are Menzel Bourguiba (which has a naval port and a metal factory), Menzel Abderrahmen and Menzel Jemil. The sources of untreated industrial and domestic wastewater of these cities, which are indicative of the near-source emissions of 


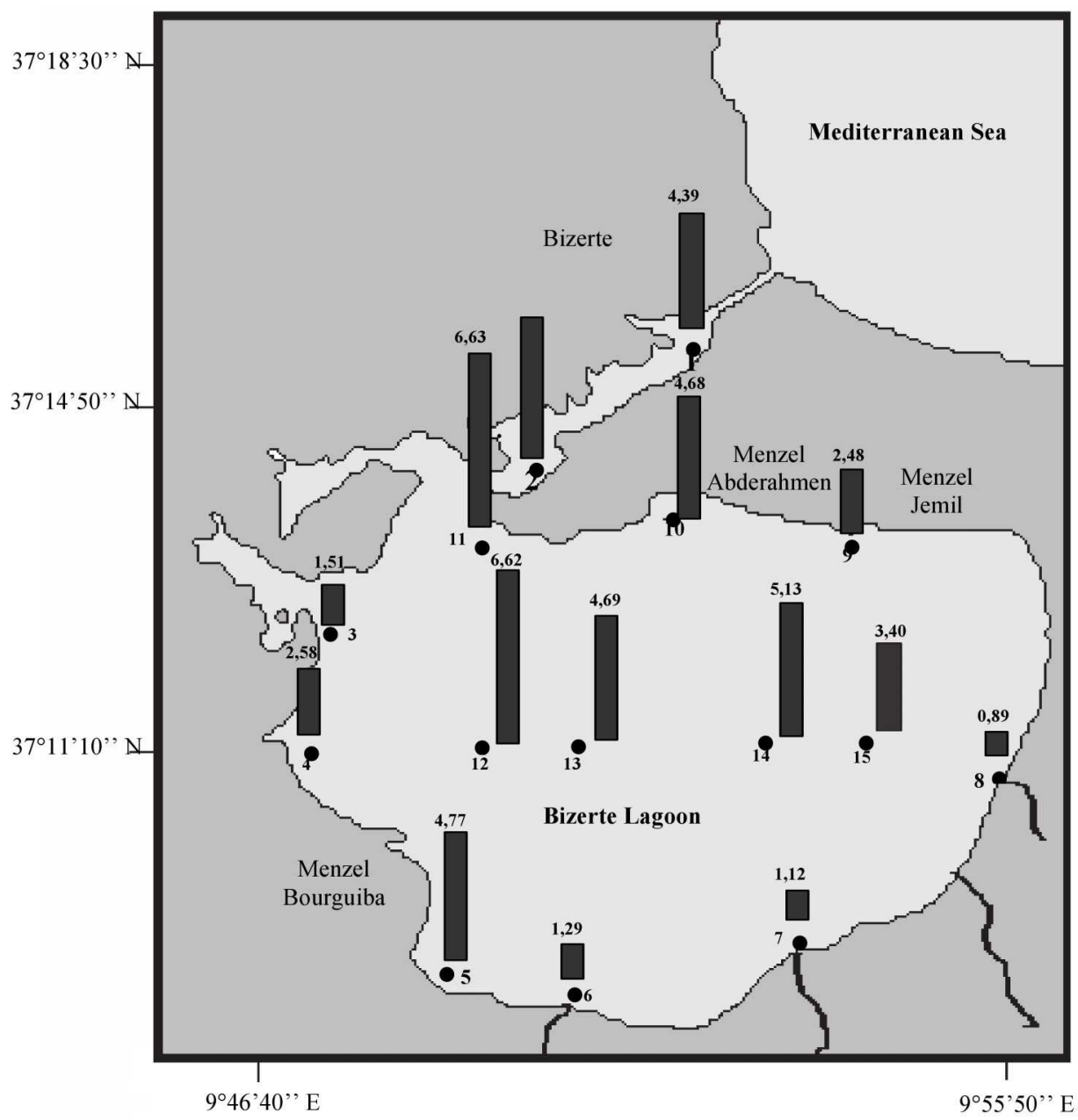

Fig. 3. Spatial distribution of $\sum \mathrm{PCB}$ in surface sediment from Bizerte lagoon

PCBs from industrial wastewater and domestic sewage, are also, the main contributors. PCBs are an industrial product; there are no known natural sources. Atmospheric depositions, runoff from the land, and food chain transport (Morrison et al., 2002; Totten et al., 2006; Davis et al., 2007) have been regarded as the major sources of PCBs in aquatic environments. Urban runoff from local watersheds is a particularly significant pathway for PCB entry into the lagoon. Since PCBs are somewhat volatile and tend to enter the atmosphere, atmospheric transport and deposition can be important processes, such as exchange between the water and the atmosphere, and between the soil and the atmosphere.

A fraction of the PCBs lost by this pathway may return to the water and land surface via deposition in the watershed and subsequent runoff. Besides, PCBs have been shown to bioconcentrate significantly in aquatic organisms (Morrison et al., 2002). Four open- 
dumping-type municipal or industrial solid waste landfills are scattered around the lagoon; the first and the biggest one is located on the edge of the canal near the cement works. The second one, in front of Menzel Bourguiba city however, the smallest ones and the farthest from the coast receive the garbage of Menzel Jemil city could escort to an important source of PCBs in the lagoon.

Although the observed trends in PCB congener composition was similar in some sediment sample (i.e. between sites 12 and 13 and between sites 14 and 15). The distribution patterns of PCBs congeners are, in general, different among the sediments of this study area, which may indicate different input sources and the establishment of correlation between the congener profiles and the sources is difficult, especially when the distance between the source and the sampling site is large. In addition the usage of PCBs in Tunisia is not well established, but the use of PCBs in transformers, electrical, and other industries is common.

Sediment-bound PCBs can affect benthic organisms. To evaluate the ecotoxicological aspect of sediment contamination, some published sediment quality guidelines and toxic equivalent (WHO-TEQ) of dioxin-like PCBs congeners were applied in this study. Although the guidelines are limited in some cases, they provide useful indicators of the effects of PCB contamination in the absence of environmental assessment criteria for PCBs in Tunisia. The effect range low value (ERL, $22.7 \mathrm{ng}$ g-1 dry weight) suggests that PCBs can exert toxic biological effects on aquatic organisms, while the effect range median value (ERM, $180 \mathrm{ng}$ g1 dry weight) indicates the high possibility of PCBs posing detrimental biological effects on aquatic organisms (Long et al., 1995). The total PCBs concentrations of the samples collected for this study do not exceed the ERM or ERL values. As regards the results obtained for dioxin-like PCBs (77, 126, 105 and 118) the concentrations for the PCB77, 105 and 118 vary from $<0.02$ ngg-1 to 0.99 ngg- 1 and only PCB126 is not detected for all sediment samples. Moreover, in the lower contaminated sites (7 and 8 ) all the studied dioxin-like PCBs were not found. The ratios between these levels and those of the total PCBs were dissimilar in all the locations studied; the dioxin-like PCBs accounted for $0-23 \%$ of the total PCBs in these samples.

\subsubsection{OCPs composition and sources identification and ecotoxicological concerns}

In case of OCPs, only 10 coastal sampling points were considered because concentrations for the most analysed pesticides were below the detection limit $(<0.010)$ (Table 3$)$. The obtained results showed that $\mathrm{HCB}$ and DDT isomers (DDT+DDE+DDD) were the predominately detected compounds in most stations with concentrations ranged between 0.02 to $0.12 \mathrm{ngg}^{-1}$ and 0.21 to $3.74 \mathrm{ngg}^{-1}$, respectively. Heptachlor was the second highest with concentration ranged between $0.03-0.3$ ngg- $^{-1}$ whereas, lindane and mirex were detected only in one station. The other pesticides were not detected in any sample.

The most contaminated stations were 2 and 3 with total pesticides concentration 3.78 ngg-1 and $3.47 \mathrm{ngg}^{-1}$, respectively. Sites $6\left(0.18 \mathrm{ngg}^{-1}\right)$ and $7\left(0.2317 \mathrm{ngg}^{-1}\right)$ were the less contaminated stations. The other sites were moderately polluted with total pesticides concentration ranged between $0.56 \mathrm{ngg}^{-1}$ in station 10 and $1.83 \mathrm{ngg}^{-1}$ in station 5 .

The composition of organochlorines and their metabolities can provide some information for a better understanding of the origin and transport of these contaminants in the environment. Microbial degradation of DDT, DDD and DDE is generally slow, resulting in 
environmental persistence of these compounds and DDT may degrade to DDD with a halflife of a few days under certain conditions (Garrison et al., 2000). DDT can be biodegraded to DDE under aerobic condition and to DDD under anaerobic condition (Kalantzi et al., 2001). Comparing the concentrations of $\sum$ DDT and its metabolites, it can be inferred whether DDTs input are recent or not (Phuong et al., 1998). The ratio of (DDE + DDD)/ $\sum$ DDT $>0.5$ can be thought to be subjected to a long-term weathering (Hites \& Day, 1992; Hong et al., 1999). In most present samples, DDE and DDD occupied the predominant percentage. Here the mean ratio of (DDE + DDD)/ $\sum$ DDT in the sediments from Bizerte lagoon was 0.85 , which indicated that the degradation occurred significantly. However, the DDT (including o,p-' and p, $\mathrm{p}^{\prime}$-) in the sediment of site 3 occupied about $50 \%$. The high levels of $\sum$ DDT and high percentage of DDT might due to intensification of the agricultural activities in areas surrounding the lagoon. In general, potential sources of OCPs pollution in the study area can be: the use of these pesticides in the past in agricultural area surrounding the lagoon, domestic sewage and atmospheric transport.

\begin{tabular}{|c|c|c|c|c|c|c|c|c|c|c|}
\cline { 2 - 14 } \multicolumn{1}{c|}{} & \multicolumn{10}{c|}{ Stations } \\
\hline OCPs & 1 & 2 & 3 & 4 & 5 & 6 & 7 & 8 & 9 & 10 \\
\hline HCB & 0.03 & 0.02 & 0.10 & 0.09 & 0.06 & 0.03 & 0.02 & 0.09 & 0.12 & 0.12 \\
\hline Lindane & nd & nd & nd & nd & nd & 0.09 & nd & nd & nd & nd \\
\hline Heptachlor & 0.27 & 0.03 & 0.06 & nd & nd & 0.06 & nd & 0.36 & 0.14 & 0.06 \\
\hline o,p'-DDT & 0.05 & 0.48 & 0.29 & nd & 0.32 & nd & nd & nd & 0.03 & nd \\
\hline p,p'-DDT & nd & 0.85 & 1.33 & nd & 0.17 & nd & nd & nd & nd & nd \\
\hline o,p'-DDE & nd & 0.06 & 0.15 & 0.14 & 0.13 & nd & nd & 0.13 & 0.22 & nd \\
\hline p,p'-DDE & 0.14 & 0.18 & 0.43 & 0.37 & 0.21 & nd & nd & nd & 0.16 & 0.13 \\
\hline o,p'-DDD & 0.33 & 0.99 & 0.48 & 0.38 & 0.40 & nd & 0.21 & 0.49 & 0.48 & 0.35 \\
\hline $\mathrm{p}, \mathrm{p}^{\prime}$-DDD & 0.09 & 1.17 & 0.60 & 0.08 & 0.51 & nd & nd & nd & 0.02 & nd \\
\hline$\sum$ DDT & 0.61 & 3.73 & 3.28 & 0.97 & 1.74 & 0 & 0.21 & 0.62 & 0.91 & 0.48 \\
\hline$\sum$ OCPs & 0.91 & 3.78 & 3.44 & 1.06 & 1.8 & 0.18 & 0.23 & 1.07 & 1.17 & 0.66 \\
\hline
\end{tabular}

Table 3. Concentrations (ngg-1, dry weight) of OCPs in surface sediments from 10 sampling stations

\section{Conclusion}

In Bizerte lagoon, Tunisian area economically very important, sediments appear moderately polluted. The contamination level appears rather low compared to those found in other ecosystems.

On the basis of this study, we can conclude that the lagoon is subject to intensive industrial activities. There are four main zones of anthropogenic influence: In zone 1 are situated oil refineries, food and ceramic industries. In zone 2 are located cements, treatment of metals (copercraft, asbestos) and sprinkling beverage factories. In zone 3 are ceramic and metallurgy activities. In zone 4 are present metallurgy activities ( $\mathrm{Fe}, \mathrm{Zn}, \mathrm{Cd}, \mathrm{Sn}, \mathrm{Hg}$ ), naval constructions and tire productions.

Because Tunisia has a long Mediterranean coast of crucial economical interest, it is obvious that a larger spatio-temporal POP monitoring has to be planned, including harbour areas. 
This is the condition to have an evaluation of the actual organic pollutants contamination of the Tunisian marine environment.

\section{References}

Aizenshtat, Z. (1973). Perylene and its geochemical significance. Geochim. Cosmochim. Acta., vol.37 pp.559-567

Alcock, RE.; Gemmill, R. \& Jones, KC. (1999). Improvements to the UK PCDD/F and PCB atmospheric emission inventory following an emissions measurement programme. Chemosphere, vol. 38 pp.759-770

Aloisi, JC. ;, Monaco A. \& Pauc, H. (1975). Mécanismes de la formation des prodeltas dans le Golf du lion. Exemple l'embouchure de l'Aude (Languedoc). Bull. Inst. Géol. Bassin Aquitaine, vol.18 pp.3-12

Bayer, M. (1959). Gas chromatography, Springer-Verlag, Berlin (proved the 450 years old work of Brunschwig, a Strassburg surgeon)

Birnbaum, LS. (1994). Endocrine effects of prenatal exposure to PCBs, dioxins, and other xenobiotics: implications for policy and future research. Environ. Health Perspect, vol.102 pp.676-9

Biterna, M. \& Voutsa, D. (2005). Polychlorinated biphenyls in ambient air of NW Greece and in particulate emissions. Environmental International, vol. 31 pp. 671-677

Bouloubassi, J. \& Saliot, A. (1993). Investigation of anthropogenic and natural organic inputs in estuarine sediments using hydrocarbon markers (NAH, LAB, PAH). Oceanol Acta, vol. 16 pp.145-61

BSI. BS 1377: 1990 British Standard Methods of Tests for Soils for Civil Engineering Purposes, Part 3 Chemical and Electrochemical Tests, British Standard Institution, London. 1990

Budzinski, H.; Jones, I.; Bellocq, J.; Pierad, C. \& Garrigues, P. (1997). Evaluation of sediment contamination by polycyclic aromatic hydrocarbons in the Gironde estuary. Mar. Chem., vol.58 pp. 85- 97

Buekens, A.; Stieglitz, L.; Hell, K.; Huang, H. \& Segers, P. (2001). Dioxins from thermal and metallurgical processes: recent studies for the iron and steel industry.Chemosphere, vol. 42 pp. $729-735$

Davis, JA.; Hetzel, F.; Oram, JJ. \& McKeeet, LJ. (2007). Polychlorinated biphenyls (PCBs) in San Francisco Bay. Environmental Research, vol. 105 pp. 67-86

Derouiche, A.; Sanda, YG. \& Driss, MR. (2004). Polychlorinated Biphenyls in Sediments from Bizerte Lagoon, Tunisia. Bull. Environ. Contam. Toxicol., vol.73 (5) pp. 810-817

Doong, RA.; Peng, CK.; Sun, YC. \& Liao, PL. (2002). Composition and distribution of organochlorine pesticide residues in surface sediments from the Wu-Shi River estuary, Taiwan. Mar. Pollut. Bull., vol.45 pp.246-53

Garrison, A.; Nzengung, V.; Avants, J.; Ellington, JJ.; Hones, WJ.; Rennels, D. \& Wolfe, NL. (2000). Phytodegradation of p.p-DDT and the enantiomers of o,p'-DDT. Environ. Sci. Technol., vol.34 pp.1663-1670

Gustafsson, O.; Haghseta, F.; Chan, C.; MacFarlane, J. \& Gschwend, PM. (1997). Quantification of the diluite sedimentary sootphase: implication for PAH speciation and bioavailability. Environ. Sci. Technol., vol.31 pp. 203- 209 
Hamdi, H.; Jedidi, N.; Yoshida, M.; Mosbahi, M. \& Ghrabi, A. (2002). Some physico-chemical properties of lake Bizerte sediments. Study on the environment pollution of Mediterranean coastal lagoons in Tunisia. Initial report, pp. 49-54

Hansen, JC. (1998). The human health programme under AMAP AMAP human health group Arctic Monitoring and Assessment Program. Int J Circumpolar Health, vol.57 pp.280- 91

Hites, RK. \& Day, HR. (1992). Unusual persistent of DDT in some western USA soils. Bull. Environ. Contam. Toxicol., vol.48 pp.259-264

Hong, H.; Chen, W.; Xu, L.; Wang, X. \& Zhang, L. (1999). Distribution and fate of organochlorine pollutants in the Pearl River Estuary. Mar. Pollut. Bull., 39 vol. pp.376-382

James, AT. \& Martin, AJ. (1952). Biochem. J., vol.50 p.679

Kalantzi, QI., Alcock, RE., Joneston, PA., Santillo, D., Stringer, RL., Thomas, GO. \& Jones, KC. (2001). The global distribution of PCBs and organochlorine pesticides in butter. Environ. Sci. Technol., vol.35 pp.1013-1018

Karickhoff, SW.; Brown, DS. \& Scott, TA. (1979). Sorption of hydrophobic pollutants on natural sediments. Water Research, vol. 13 pp.241-248

Kelly, CA.; Law, RJ. \& Emerson, HS. (2000). Methods of analysing hydrocarbons and polycyclic aromatic hydrocarbons (PAH) in marine samples. The Centre for Environment, Fisheries and Aquaculture Science (CEFAS) Science Series, Aquatic Environment Protection: Analytical Methods No. 12, Lowestoft, England

Knezovich, JP.; Harrison, FL. \& Wilhelm, RG. (1987). The bioavailability of sedimentsorbed organic chemicals: a review. Water Air Soil Pollut., vol.32 pp.233-45

LaFlamme, RE. \& Hites, RA. (1978). The global distribution of polycyclic aromatic hydrocarbons in recent sediments. Geochim. Cosmochim. Acta, vol.42 pp. 289-303

Law, R. \& Andrulewicz E. (1983). Hydrocarbons in water, sediment and mussels from the Southern Baltic Sea. Mar. Pollut. Bull. vol.14 pp.289-93

Long, ER.; MacDonald, DD.; Smith, SL. \& Calder, FD. (1995). Incidence of adverse biological effects within ranges of chemical concentrations in marine and estuary sediments. Environmental Management, vol. 19 pp.81-97

Montone, RC.; Taniguchi, S. \& Weber RR. (2001). Polychlorinated Biphenyls in Marine Sediments of Admiralty Bay, King George Island, Antarctica. Mari. Pollut. Bull., vol. 42 pp.611-614

Morrison, HA.; Whittle, DM., \& Haffner, GD. (2002). A comparison of the transport and fate of polychlorinated biphenyl congeners in three Great Lakes food webs. Environmental Toxicology and Chemistry, vol. 21 pp. 683-692

National Research Council (NRC) (1985). Oil in the Sea: Inputs, Fates and Effects. National Academic Press, Washington, DC, 1985

Neff, JM. (1979). Polycyclic aromatic hydrocarbons in the aquatic environment sources, fates and biological effects. London7 Applied Science Publishers, 262 pp.

Page, DSS.; Boehm, PD.; Douglas, GS.; Bence, EA.; Burns, WA. \& Mankiewicz, PJ. (1999). Pyrogenic polycyclic aromatic hydrocarbons in sediments record past human activity: a case study in Prince William sound, Alaska. Mar. Pollut. Bull., vol.38 pp. 247-260 
Phuong, PK.; Son, CPN.; Sauvain, JJ. \& Tarradellas, J. (1998). Contamination by PCB_s, DDT_s and heavy metals in sediments of Ho Chi Minh City_s canals, Vietnam. Bull. Environ. Contam. Toxicol., vol.60 pp.347-354

Stockholm Convention on Persistent Organic Pollutants. UNEP: persistent organic pollutants 2001. http://www.pops.int/documents/convtext/ convtext_en.pdf

Swarz, R. (1999). Consensus sediment quality guidelines for polycyclic aromatic hydrocarbons mixtures. Environ. Toxicol. Chem., vol.18 pp. 780- 787

Tietz, NW. (1970). Fundamentals of Clinical Chemistry, WB. Saunder \& Co. Philadelphia, Pa., p.118

Totten, LA.; Panangadan, M.; Eisenreich, SJ.; Cavallo, GJ. \& Fikslin, TJ. (2006). Direct and indirect atmospheric deposition of PCBs to the Delaware River Watershed. Environmental Science Technology, vol. 40 pp. 2171-2176

Trabelsi, S. \& Driss, MR. (2005). Polycyclic aromatic hydrocarbons in superficial coastal sediments from Bizerte Lagoon, Tunisia. Mar. Pollut. Bull., vol.50 pp. 344-359

Venkatesan, MI. (1988). Occurrence and possible sources of perylene in marine sediments-a review. Mar. Chem., vol.25 pp. 1-27 


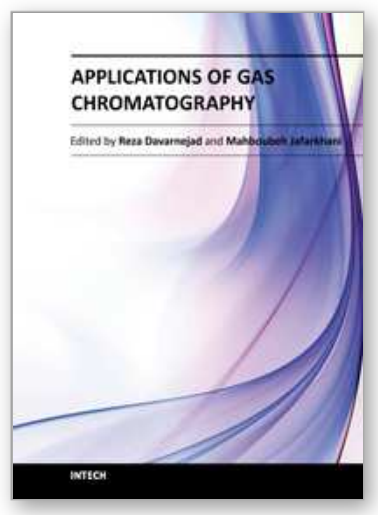

\section{Applications of Gas Chromatography \\ Edited by Dr. Reza Davarnejad}

ISBN 978-953-51-0260-1

Hard cover, 132 pages

Publisher InTech

Published online 07, March, 2012

Published in print edition March, 2012

This valuable book aims to provide a connection between various chromatography techniques and different processes. Authors applied these techniques in supercritical technology, medical, environmental, physique and chemical processes. Most of them prepared mathematical support (such as correlation) for their original results obtained from the chromatography techniques. Since chromatography techniques (such as GC, HPLC \& etc) are separating and analyzing methods, this chapters will help other researchers and young scientists to choose a suitable chromatography technique. Furthermore, this book illustrates the newest challenges in this area.

\section{How to reference}

In order to correctly reference this scholarly work, feel free to copy and paste the following:

Trabelsi Souad, Ben Ameur Walid, Derouiche Abdekader, Cheikh Mohamed and Driss Mohamed Ridha (2012). POP and PAH in Bizerte Lagoon, Tunisia, Applications of Gas Chromatography, Dr. Reza Davarnejad (Ed.), ISBN: 978-953-51-0260-1, InTech, Available from: http://www.intechopen.com/books/applications-ofgas-chromatography/pop-in-the-bizerte-lagoon

\section{INTECH}

open science | open minds

\section{InTech Europe}

University Campus STeP Ri Slavka Krautzeka 83/A 51000 Rijeka, Croatia Phone: +385 (51) 770447 Fax: +385 (51) 686166 www.intechopen.com

\section{InTech China}

Unit 405, Office Block, Hotel Equatorial Shanghai No.65, Yan An Road (West), Shanghai, 200040, China 中国上海市延安西路65号上海国际贵都大饭店办公楼405单元 Phone: +86-21-62489820

Fax: +86-21-62489821 
(C) 2012 The Author(s). Licensee IntechOpen. This is an open access article distributed under the terms of the Creative Commons Attribution 3.0 License, which permits unrestricted use, distribution, and reproduction in any medium, provided the original work is properly cited. 